SHS Web of Conferences 2, 00026 (2012)

DOI: $10.1051 /$ shsconf $/ 20120200026$

(C) Owned by the authors, published by EDP Sciences, 2012

\title{
Determinants of juvenile delinquent behaviour in the family
}

\author{
I. Razgale
}

Rīga Stradinsš University, Latvia

\begin{abstract}
Children and adolescents are one of the most vulnerable social groups in the community. Copenhagen declaration has emphasized the fact that particular efforts should be devoted to children and adolescent protection with an aim for extension of social protection and decrease of easy vulnerability of humans. Children and adolescent behaviour is like a mirror which depicts the processes going on in the society, as well as the existing social and economic controversies. At present one can witness negative tendencies in children and adolescent behaviour in Latvia: they drop school early, lead a vagrant life, get used to drugs, violence grows, especially that of severe crimes. In the Resolution of the European Parliament of June 21, 2007 "On Juvenile Delinquency - Role of Women, Family and Community" it is also written, that children enter the world of crime much earlier. Certain emotional and behavioural peculiarities of children and adolescents can be taken as a norm at a definite age, however, there exist also such behavioural peculiarities, which essentially differ from the accepted norms. Causative factors of delinquent behaviour, as well as its consequences, are at a level of multiple systems. But, the first and the most significant in any person's life is the family, and, consequently, it is important to learn and analyze what are the factors in the family which determine the formation of delinquent behaviour.
\end{abstract}

Key words: adolescent, delinquent behaviour, determinants, family

At each age period there may develop certain relationship with the microenvironment - the family, class, group, etc.; with a mesoenvironment - school, community, where one lives and the macroenvironment the society and the state (Špona, 2001; 162).

From the very first moment when a child comes into this world, he/she becomes a participant of socialization process. The first environment the child enters is his/her family. This is where the child acquires the first norms, traditions, stereotypes of behaviour, knowledge, values, etc. Later in this socialization process the peers, various professionals, mass media, various institutions and the society as a whole get involved. There exist a great number of socializers who affect the child's inclusion into the society, formation of one's behaviour, views and values. It means, that socialization or the process of social formation is connected with a child's and later an adolescent's upbringing, or the influence of his/her personality development, targeted at certain criteria of values (Gudjons, 2007; 169, 198).

What kind of a society member does this adolescent become in the interaction of these different systems and the process of social formation? No doubt, each system determines a young person's views, values and behaviour.

But, not forgetting the fact, that "children willingly determine their development themselves" (Gudjons, 2007; 184), the influence of the family environment is essential, and it may be one of the most significant factors in relation to the risk of formation of delinquent behaviour.

The aim of the study: to study the factors affecting the formation of juvenile delinquent behaviour in the family.

Methods: Statistical data analysis, case analysis. By emphasizing the factors affecting the juvenile delinquent behaviour, the attention in case analysis is turned just to the influence of the family environment.

This is an Open Access article distributed under the terms of the Creative Commons Attribution License 2.0, which permits unrestricted use, distribution, and reproduction in any medium, provided the original work is properly cited. 


\section{SHS Web of Conferences}

\section{Results}

Despite the fact, that juvenile delinquency rate in the last years is receding, the tendency has been observed for the increase of repeated crimes. According to the statistical data of the Information Centre of the Ministry of the Interior of the Republic of Latvia, 15858 persons have committed crimes in 2010, of them 984 are minors from 14-18 years of age. 128 adolescents have committed criminal offences being in alcohol intoxication, 8 -under the influence of drugs, 5-under the influence of psychotropic substances, which means that the rate of criminal offences has increased due to intoxicating substances (in comparison: $2009-13 \%$ of all registered criminal offences of minors; 2010-29,5\%). Like the most widespread criminal offence committed by adolescents, one has to mention: thievery (Criminal Law (further on-CL) 175. p.-180. p.) -512 (among them: from flats -77 , from trade centers -168 and from automobiles - 11), intentional destruction or damage of property (CL 185. p.) - 125, robberies (CL 176. p.) -42 , etc.

In 2010 in preventive records of the State Police were registered 900, and at the end of the reporting period 1115 juvenile offenders were in the records of Minors Affairs Inspectors of State Police and 1135 minors came into sight of State Police due to criminal offences, vagrancy, etc. (www.vp.gov.1v/doc_upl/ nepilngadigie_ 2010lab.doc).

Where to look for the reasons of such behaviour, and what can provoke them? Are these family conditions and the relationship between family members, or relationship with peers, or other influential adults outside the family, or these are personality traits? Certainly, these may be any of the factors mentioned, but it may be also a combination of factors which determines an adolescent's behaviour, violating the public accepted norms and committing a crime.

Referring to the statement, that the formation of delinquent behaviour is primarily affected by microsocial environment, i.e., the family and the situations that occur in this environment, one can emphasize the family role in the development of one's personality and to point out, that with the Order Nr. 155 of the Ministry of Welfare of the Republic of Latvia, December 18, 2009, among the priorities of the policy of the Ministry of Welfare for 2010-2014, the family is highlighted as having an important role in a child's full development in favourable environment (ww.lm.gov.lv/upload/ministrija/prioritates/lmprior2010_2014.pdf).

But, in order an adolescent could be able to fully develop, the family has to ensure favourable and safe environment. It can be implemented through the realization of family functions:

- The family has to provide for a person's physical end emotional development (retrospective study with a participation of 102 offenders at the age of 15-18 years, showing, that the anxiety caused in early childhood due to parents' lack of communication has determined these adolescents' wish to respond in an antisocial manner to various events in their lives).

- The family plays an essential part in the adolescent's gender and role in socialization (in the family an important role is played by father in the gender socialization, since it is him who differentiates his relationship with a daughter and a son, supporting the son's activity and aggression, the daughter's femininity and tenderness).

- The family plays the leading role in an adolescent's cognitive development (intellect can be related to parents' social status - adolescents who do not use favourable conditions for their development, and adolescents who are able to overcome unfavourable developmental conditions).

- In the family are formed: a young person's orientations towards fundamental values in social and interrelated relationship spheres; life efforts, plans, types for their achievement, etc.

- The family plays a big role in acquiring norms and performance of family roles.

- The family fulfills the function of socially-psychological support, which affects an adolescent's self-esteem, degree of self-respect, self-acceptance and self-realization efficiency (a child should not lack a sense of protection, because otherwise there are formed such features, which make it difficult for a child find his/her place in the society; in adolescents and young people, in its 


\section{Int. Conf. SOCIETY. HEALTH. WELFARE; Congr. of Rehabilitation Doctors of Latvia}

turn, there may develop hostility towards parents, distrust to adults in general, difficulties in communication with peers and surrounding environment; antisocial atmosphere in the family may become the reason for juvenile crimes) (Мудрик, А.В., 2006; 157-158).

Therefore, whether the family can be favourable or unfavourable environment is greatly determined by various factors, for example, family structure, educational level of the family members, employment, social conditions, life style specificities, norms and values existing in the family, psychological microenvironment, etc.

Theoretically analyzing the possible provoking factors for the development of delinquent behaviour, one can identify the following:

- frustration (on one hand-need for tender care, affection, and on the other hand-inadequate parents' attitude);

- physical and psychological cruelty, power cult;

- insufficient father's influence (for example, father's absence and his constant lack);

- trauma (disease, one parent's death, violence, divorce);

- indulgence of desires; insufficient demands from parents' side and inability to set the demands and achieve their performance;

- coordination of demands and inadequacy from parents' side, resulting in misunderstanding of behavioural norms;

- change of parents/primary caregivers (guardians, foster parents, etc.);

- chronic conflicts and abuse in parents' relationship;

- unaccepted parental personality features (for example, combination of undemanding father and indulgent mother);

- acquiring of delinquent values (open or hidden) through learning in the family or in some other group (Змановская, Е.В. 2006; 103).

But, viewing the provoking factors for delinquent behaviour in the family environment, and excluding the factors influencing the adolescent from the family, then, in the context of case analysis, we can find certain signs (see Table 1).

Summarizing the data acquired in specific cases, one can see the regularities in the juvenile behaviour corresponding to what is going on in the family. But, one has to take into account, that when studying such regularities and adolescent-family interaction, juvenile behavioural scenario can develop differently, meaning, that in youngsters' behaviour there will not be observed any violations of accepted public norms and regulations, therefore it is important to study such exceptions as well. The family does not exist separately from processes going on in the society and is not protected from the influence of external factors, however, in the very family system various protective factors which limit the adolescents' submission to the risk factors may exist (Shader; 3-4).

\section{Conclusions}

1. Certain adolescent behavioural peculiarities can be estimated as a norm at a certain age (grouping, emancipation tendencies, imitation reactions, etc.), yet, there exist also such behavioural peculiarities, which essentially differ from the above-mentioned.

2. Analyzing the data on violence of the Information Centre of the Ministry of the Interior in the country, and paying a special attention just to the minors' offences, one can conclude, that the minors' crime rate in the last years has a tendency to decrease, though there is also a tendency for the repeated offences committed to grow.

3. Performing the case analysis, the connection of delinquent behaviour with the behavioural patterns existing in the family environment was found. Adolescents' vagrancy, thefts, aggression towards other people and animals, destruction or damage of other people's property, as well as other 


\section{SHS Web of Conferences}

Table 1.

\begin{tabular}{|l|l|}
\hline Factors in family environment & Adolescent's behaviour \\
\hline $\begin{array}{l}\text { 1st }^{\text {st }} \text { family, step-father has entered the } \\
\text { accept; mother is all day long at work and } \\
\text { cannot devote sufficient time and } \\
\text { attention to son; he suffers from adult's } \\
\text { abuse. }\end{array}$ & $\begin{array}{l}\text { vagrancy; aggressiveness; rude attitude to } \\
\text { others; theft (registered in Minors Affairs } \\
\text { Office records) }\end{array}$ \\
\hline $\begin{array}{l}2^{\text {st }} \text { case: parents are alcohol abusers; } \\
\text { since early childhood they have forced } \\
\text { the child to use alcoholic drinks (with an } \\
\text { aim-let the child sleep and the parents } \\
\text { can leave the child alone without taking } \\
\begin{array}{l}\text { care); violence (have tethered with chains } \\
\text { to the bed); parents have dealt with } \\
\text { thievery }\end{array}\end{array}$ & $\begin{array}{l}\text { aggressiveness; sadistic attitude to } \\
\text { animals }\end{array}$ \\
\hline $\begin{array}{l}3^{\text {st }} \text { case: an adolescent has suffered from } \\
\text { abuse; father has been imprisoned (for } \\
\text { beating somebody); father is violent } \\
\text { towards mother; father abuses alcohol; } \\
\text { lack of means of subsistence; there are } \\
\text { often strangers in the family }\end{array}$ & $\begin{array}{l}\text { theft of property, documents and money, } \\
\text { aggressiveness towards others }\end{array}$ \\
\hline $\begin{array}{l}4^{\text {th }} \text { case: neglect (parents do not show } \\
\begin{array}{l}\text { interest and care towards the adolescent), } \\
\text { alcohol abuse }\end{array}\end{array}$ & $\begin{array}{l}\text { thievery; vagrancy; addictions (smoking, } \\
\text { physically abusive (has caused intentional } \\
\text { injuries) towards peers }\end{array}$ \\
\hline
\end{tabular}

offences are related to young people's acquired experience and are exposed as consequences experienced in the family.

\section{References}

[1] Gudjons, H. Pedagoǵijas pamatatziņas. Rīga: Zvaigzne ABC, 2007.

[2] Špona, A. Audzināšanas teorija un prakse. Rīga: RaKa, 2001.

[3] Shader, M. Risk Factors for Delinquency: An Overview-Office of Juvenile Justice and Delinquency Prevention.

[4] Мудрик. А.В. Социализация человека: Учебное пособие для студ высш. учеб. заведений. 2. изд. Москва: Издательский центр «Академия», 2006.

[5] Змановская, Е.В. Девиантология: психология отклоняющегося поведения: Учебное пособие для стүд. высщ. учеб. заведений. 3. изд. Москва: Издательский центр «Академия », 2006.

[6] Pārskats par nepilngadīgo noziedzību, cietušiem bērniem, stāvokli ceļu satiksmē un prevencijas jomā 2010.gada 12 mēnešos. www.vp.gov.lv/doc_upl/nepilngadigie_2010lab.doc

[7] Rīkojums par Labklājības ministrijas politikas prioritātēm 2010.-2014. gadam. www. lm. gov.1v/upload/ministrija/prioritates/lmprior2010_ 2014.pdf 